\section{ECONOMICS}

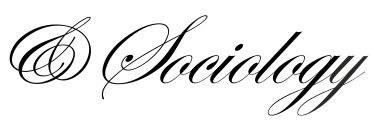

Khanh, M.T.H, \& Thu, P. A. (2019). The effect of financial leverage on real and accrual-based earnings management in Vietnamese firms. Economics and Sociology, 12(4), 299-312. doi:10.14254/2071-789X.2019/12-4/18

\title{
THE EFFECT OF FINANCIAL LEVERAGE ON REAL AND ACCRUAL-BASED EARNINGS MANAGEMENT IN VIETNAMESE FIRMS
}

\author{
Khanh Mai Thi Hoang, \\ 1 University of Economics and \\ Law, Ho Chi Minh City, \\ Vietnam \\ 2 Vietnam National University, \\ Ho Chi Minh City, VietnamCity, \\ Vietnam \\ E-mail:kbanbbtm@uel.edu.vn
}

Thu Anh Phung *,

Nguyen Tat Thanh University, Ho

Chi Minh City, Vietnam

E-mail:patbu@ntt.edu.vn

${ }^{*}$ Corresponding author

Received: January, 2019

1st Revision: May, 2019

Accepted: November, 2019

DOI: $10.14254 / 2071-$

789X.2019/12-4/18

JEL Classification: M40, M41
ABSTRACT. Our research examines the effect of leverage on the form and extent of earnings management in Vietnamese listed firms. We use panel data of 241 companies on Vietnam stock markets in the period from 2010 to 2016 (1687 firm-years) and conduct GMM regression. Four models are employed to estimate the level of discretional accruals and real earnings management. Our research finds a positive relationship between leverage and earnings management, which is consistent to "debt hypothesis". Furthermore, a preference for real earnings management over accrualbased earnings management is observed among highly leverage firms. The findings notice the substitution between these two forms of earnings management and reinforce full attention to both accrual-based earnings management and real activities manipulations rather than to separated earnings management strategy.

Keywords: firm leverage, accrual-based earnings management, real earnings management, Vietnam

\section{Introduction}

Earnings management is one of the most discussed topics, arousing continuous interests in accounting literature. There is a large extent of research examining the effects of firm's characteristics on earnings management practice, in which, leverage is an important and informative indicator.

In this study, our main focus is the effect of leverage on both accrual-based earnings management and real earnings management. Especially, we are interested in the question of whether this effect is different in the context of highly indebted firms. We examine 241 
companies on Vietnam stock markets (HNX and HOSE) in the period from 2010 to 2016 and employ four models to estimate discretional accruals and real earnings management.

Regarding the effect of leverage on earnings management, there are two streams of arguments. On the one hand, positive accounting, especially "debt hypothesis" expects the motivations of managers to manage earnings in order to avoid debt covenant violations as breaching these contractual terms can be costly (Watts \& Zimmerman, 1986). Moreover, outside the context of debt covenants, earnings can also be manipulated to achieve favorable contract terms (Rodríguez-Pérez \& van Hemmen, 2010; Watts \& Zimmerman, 1986) or to maintain relationship for additional debts (Ronen \& Yaari, 2008). On the other hand, control hypothesis of Jensen (1986) mentions debt financing as an effective monitoring mechanism to reduce manager's opportunistic behaviors thanks to the scrutiny of bofth creditors and investors. Additionally, the contractual commitments for debt repayments leaves a low level of free cash flow available, which limit manager's discretions in sub-optimal projects (Jensen, 1986). Empirical research has found a large extent of evidence supporting "debt hypothesis" (DeFond and Jiambalvo (1994); Sweeney (1994); Becker, DeFond, Jiambalvo, and Subramanyam (1998); DeAngelo, DeAngelo, and Skinner (1994); B. H. Kim, Lisic, and Pevzner (2010); Jha (2013); Alzoubi (2017); Lazzem and Jilani (2018)). However, the controlling effect of debts to increase financial reporting quality is also suggested through other research (Ahn \& Choi, 2009; Alsharairi, 2012; Jelinek, 2007; Rodríguez-Pérez \& van Hemmen, 2010).

Despite the vibrant literature on earnings management in developed countries, research on this topic in Vietnam is still limited. Since the reformations in 1986, Vietnam's economy has witnessed a rapid development thanks to government's great efforts on improving business environment. However, the economy is still partially opened, with the capital market being in the early stage (Vo, 2017). Consequently, the issues of information asymmetries and market transparency can be considerable challenges to financial reporting quality in Vietnam. When it comes to the effect of leverage on earnings management, the nature of debt financing is worth to consider. There are three main sources of finance for Vietnamese listed firms including equity market, bond market and bank system. While equity market is rather insufficient, shortterm oriented and bond market is considered to be small and inactive, companies in Vietnam mainly use bank loans as their main source of finance (Phan, 2018; Vo, 2017). Owing to the nature of debt financing and specific market context, the impact of leverage on earnings management among listed firms in Vietnam is expected to far more different to that in developed countries.

Our research is motivated by the following reasons. First, the effect of leverage on earnings management can be seen from different theoretical lens, with controversial empirical evidences. As the evidence from empirical research are still inconclusive, our research aims to shed more lights on investigating this issue. Second, in the contemporary globalization accounting theme, specific characteristics of different countries are worth considering. Not to mention, earnings management practices can be disparate between countries and international evidence should be taken into consideration (Alzoubi, 2017). Although the effect of leverage on earnings management has been investigated in developed countries, the research on this issue in Vietnam is still limited. Empirical evidence in Vietnam, which takes specific market contexts into account, can provide an international aspect of this issue. Third, in studying the effect of leverage on earnings management, most of prior research focused on accrual-based earnings management (Alzoubi, 2017; DeFond \& Jiambalvo, 1994; Jelinek, 2007; Jha, 2013; Lazzem \& Jilani, 2018; Sweeney, 1994). However, as manager can use accrual-based earnings management and real activities manipulations as substitutes (Zang, 2011), the effect of leverage should be considered in a comprehensive view of both these strategies, rather than in isolation. 
Our research contributes to literature by measuring both accrual-based earnings management and real activities manipulation and examining the substitution of these in different debt financing contexts.

The rest of the paper proceeds as follows. The next section of the paper shows the literature and develops the research hypotheses; section 3, 4 and 5 presents the methodology, section 6 is the findings and discussion, finally section 7 provides the limitations and a few recommendations.

\section{Literature review}

Managers have great motivations to manage earnings, ranging from improving bargaining power and achieving more favorable conditions in debt contract negotiation (Rodríguez-Pérez \& van Hemmen, 2010; Watts \& Zimmerman, 1986), to avoid debt covenant violations, or to maintain relationship for additional debt raising (Ronen \& Yaari, 2008). Noticeably, "Debt hypothesis" suggests that firms engage in earnings management to avoid debt covenant violations as breaching loan's contracts can be costly (Watts \& Zimmerman, 1986). First, the disclosure of violations, either compulsory or voluntarily can results in the increase in cost of debt and the decline in investment effectiveness (Nini, Smith, \& Sufi, 2009; Roberts \& Sufi, 2009), or the acceleration of payment and reduction in credit line (Jha, 2013). Second, if the firms violate debt covenants but manage to renegotiate the loan contracts, avoiding disclosure of violations, the consequences of these renegotiation are mostly unfavorable in terms of loan principal or interest (B. H. Kim et al., 2010). Third, transaction fees related to legal, service fee, time and resources also make the cost of renegotiation worth considering (B. H. Kim et al., 2010). Last, violation of debt contracts also links to the competence of managers and harms their compensation and job security (Jha, 2013; Nini et al., 2009). As most of debt covenants are based on accounting figures, managers are motived to manipulate these metrics, reducing the probability of contractual violations.

The extent of relationship between leverage and earning management is also more severe in highly leveraged firms. Debt overhang theory of Myers (1977) argues that when the firms are highly indebted, most of benefits from current investments are expected to transfer to creditors through interest payments. Shareholders, therefore, have less motivation of proceeding new investments, and the firms would forgo valuable projects in the future. This under-investment problem can diminish the firms' growth opportunities and leads to a drop in stock market price. Empirical research has showed consistent evidence that the increase in leverage ratios results in the deterioration of stock returns and future earnings (Bradshaw, Richardson, \& Sloan, 2006; Cai \& Zhang, 2011; Cohen \& Lys, 2006; Penman, Richardson, \& Tuna, 2007). In their research, Cai and Zhang (2011) find that the increase in leverage lowers the stock returns. Especially, this negative effect is more severe for the firms suffering higher leverage level, higher default risks or financial distress. In addition, the increase in leverage level also links to the reduction in future investments, in which the firms reject positive NPV but low ROA projects. These such under-investment problems would harm future growth opportunities and make the firms less attractive in shareholder's perceptions. It is also unfavorable to manager in the aspects of reputations, compensations as well as job security (Graham, Harvey, \& Rajgopal, 2005). Consequently, managers have incentives to dress up company's financial pictures to improve the situations and mitigate under-investment problems effects.

A large amount of research shows a positive association of leverage and earnings management. Consistent to debt covenant hypothesis, DeFond and Jiambalvo (1994) and Sweeney (1994) finds that managers in high default risks firms tend to engage in income- 
increasing changes to reduce the probability of technical default. DeAngelo et al. (1994) argues that when technical defaults are unavoidable, managers tend to manage earnings downward to attain more advantageous during the contract renegotiations. Research of B. H. Kim et al. (2010) finds that firms employ earnings management to avoid debt covenants violation and the level of earnings management is higher when the firms' bankruptcy risks increase in previous year. Research of Jha (2013) concurs the evidence for both upward and downward EM before or in the quarter a violation occurs. However, no excessive earnings management are observed among highly indebted firms. This implies the effects of "debt hypothesis", but do not support the higher effects of high leverage on earnings management practice. By contrast, Alzoubi (2017) examines two distinct samples of low debt and high debt companies and shows different results between two groups. While low debt can diminish earnings management practice, high debt is significantly associated with earnings management practice in order to avoid contracts violations. Lazzem and Jilani (2018) also supports debt covenant hypothesis by showing that highly indebted firms manipulate earnings to address stakeholders' expectations. Especially, the motivations are significantly high for those who undergo increasing leverage.

Despite a vast research relating to the positive association between leverage and earnings management, this issue is also viewed from different theoretical lens. Firstly, control hypothesis of Jensen (1986) suggests that firms with higher level of leverage subject to greater scrutiny of both creditors and investors, constraining manager's opportunistic discretions. Secondly, thanks to contractually committed interests and debt repayments, highly leveraged companies have low free cash flow available, avoiding manager engage in sub-optimal projects and reducing earnings management practice. Ahn and Choi (2009) mentions bank monitoring as a critical part in corporate governance of bank-dependent firms, which reduce the level of discretionary accruals. Rodríguez-Pérez and van Hemmen (2010) argues that it may be efficient for creditors to increase their monitoring in the context of higher leverage, as this constrains managers' opportunities to engage in earnings management practice. Similarly, Jelinek (2007) also finds that firms with leverage increases create less discretionary accruals to artificially inflate earnings. Using a sample of US non-cash acquirers, Alsharairi (2012) finds a significant evidence of income-increasing discretionary accruals before the announcement of M\&A. Noticeably, there is no such manipulation founded among highly leveraged firms. This supports the argument that leverage can be a governance mechanism to enhance the quality of corporate reporting and reduce managers' opportunistic behaviors before special events such as M\&A.

Concerning earnings management strategies, managers can choose between real activities manipulation (REM) and accrual-based earnings management (AEM). REM refer to operational, investing or financing decisions made by managers to intentionally distort accounting performance (El Diri, 2017). Managers can alter economic decisions relating to revenue, production and discretionary expenses to manage earnings (Graham et al., 2005; Roychowdhury, 2006). Meanwhile, AEM takes advantage the flexibility in accounting methods or estimates to achieve target earnings without changing underlying economic transactions (El Diri, 2017). Literature has indicated that REM is more harmful for firms' future performance as this strategy impact directly to company's cash flow and may make the firm deviate from its optimal business strategies (Anagnostopoulou \& Tsekrekos, 2016; Cohen \& Zarowin, 2010; Graham et al., 2005). However, REM is more difficult to be detected than AEM as it can be covered under the form of normal business transactions (Anagnostopoulou \& Tsekrekos, 2016; Cohen, Dey, \& Lys, 2008; Cohen \& Zarowin, 2010; Gao, Gao, \& Wang, 2017; Zang, 2011). Especially, in the context of greater scrutiny, the use of AEM can be restrained and substituted by REM. In highly indebted firms, high leverage level links to high credit risks, default risks, which draws the attention of capital providers. Therefore, the use of AEM can be constrained due to the scrutiny and monitoring of creditors and investors and firms tend to switch to REM 
which can be more difficult to be detected (Anagnostopoulou \& Tsekrekos, 2016; Roychowdhury, 2006; Zang, 2011).

\section{* Hypothesis development}

A large extent of research showed significant relationship between leverage and earnings management practices, however, with different directions. In this research, we built our expectation based on "debt hypothesis" (Watts \& Zimmerman, 1986) and propose to test the following hypothesis:

H1: There is an association between leverage and earnings management.

Considering the context of highly leveraged firms, extant literature finds the preference for REM over AEM (Anagnostopoulou \& Tsekrekos, 2016; Roychowdhury, 2006; Zang, 2011). Therefore, we propose the following hypothesis:

$\mathrm{H} 2$ : In highly leveraged firms, leverage has a positive association with REM and a negative association with AEM.

\section{Earnings management measure}

Dependent variables include real earnings management and accrual-based earnings management, which are proxied as follows:

\section{Real earnings management measure:}

Following research of Roychowdhury (2006), we proxy the level of real earnings management through three metrics:

- Abnormal levels of cash flow from operations (REM_CFO) : To increase earnings, managers can accelerate revenue by offering discounts or loosen credit terms. However, this results in lower cash flow per sale in the current period. Follow Roychowdhury (2006), the abnormal levels of cash flow (REM_CFO) can be captured by actual CFO minus normal $\mathrm{CFO}$, calculated using the estimated coefficients from below model :

$$
\frac{C F O_{i, t}}{A_{i, t-1}}=\beta_{1} \frac{1}{A_{i, t-1}}+\beta_{2} \frac{\text { SALES }_{i, t}}{A_{i, t-1}}+\beta_{3} \frac{\Delta \text { SALES }_{i, t}}{A_{i, t-1}}+\varepsilon_{i, t}
$$

Where: $\mathrm{CFO}_{i, t}$ : Cash flow from operation of firm $i$ in period $t ; A_{i, t-1}$ : Total assets of firm $i$ in year $t$-1; Sales $i, t$ : Sales of firm $i$ in year $t ; \Delta$ Sales $_{i, t}$ : Sales of firm $i$ in year $t$ less sales of firm $i$ in year $t-1$; $\varepsilon_{i, t}$ : a residual term that measure the level of abnormal cash flow (REM_CFO) of firm i in year $t ; \beta_{1}, \beta_{2}, \beta_{3}$ are firm-specific parameters.

- Production costs (REM_PROD): Manager can also increase earnings through increased production, then decrease fixed cost per unit. The level of abnormal production cost (REM_PROD) is the difference between actual cost and normal cost. Follow Roychowdhury (2006), we run following model to estimate normal level of production cost:

$$
\frac{\operatorname{PROD}_{i, t}}{A_{i, t-1}}=\beta_{1} \frac{1}{A_{i, t-1}}+\beta_{2} \frac{\operatorname{SALES}_{i, t}}{A_{i, t-1}}+\beta_{3} \frac{\Delta \mathrm{SALES}_{i, t}}{A_{i, t-1}}+\beta_{4} \frac{\Delta \mathrm{SALES}_{i, t-1}}{A_{i, t-1}}+\varepsilon_{i, t}
$$

Where: $P R O D_{i, t}:$ The sum of cost of goods sold and change in inventory of firm i in year $t ; A_{i, t-}$ 1: Total assets of firm $i$ in year $t-1$; Sales $s_{i, t}$ : Sales of firm $i$ in year $t$; $\Delta$ Sales $i, t$ : Sales of firm $i$ in year $t$ less sales of firm $i$ in year $t-1 ; \Delta$ Sales $_{i, t-1}$ : Sales of firm $i$ in year $t-1$ less sales of firm $i$ in year $t$-2; $\varepsilon_{i, t}$ : a residual term that measure the level of abnormal production costs (REM_PROD) of firm $i$ in year $t ; \beta_{1}, \beta_{2}, \beta_{3}, \beta_{4}$ are firm-specific parameters. 
- Discretionary expenses (REM_DISX): To improve earnings, managers can make a reduction in discretionary expenses regarding advertising, R\&D and SG\&A expenses. Similarly, we model the level of normal discretionary expenses as follow:

$$
\frac{\operatorname{DISCEXP}_{i, t}}{A_{i, t-1}}=\beta_{1} \frac{1}{A_{i, t-1}}+\beta_{2} \frac{\operatorname{SALES} S_{i, t-1}}{A_{i, t-1}}+\varepsilon_{i, t}
$$

Where: DISEXP $P_{i, t}$ : The sum of Selling and Marketing Expenses and General and Administrative Expenses of firm $i$ in year $t ; A_{i, t-1}$ : Total assets of firm $i$ in year $t-1$; Sales $i_{i, t-1}$ : Sales of firm $i$ in year $t-1 ; \varepsilon_{i, t}:$ a residual term that captures the level of abnormal discretionary expenses (REM_DISX) of firm $i$ in year $t ; \beta_{1}, \beta_{2}$ are firm-specific parameters.

Follow Cohen and Zarowin (2010), we multiple REM_CFO and REM_DISX by negative one to ensure the uniformity. The higher value of these metrics indicates higher level of real earnings management. We calculate two aggregated metrics to capture the total effects of real earnings management:

$$
\begin{gathered}
R E M 1=R E M_{D I S X} *(-1)+R E M_{-} P R O D \\
R E M 2=R E M_{C F O} *(-1)+R E M_{D I S X} *(-1)
\end{gathered}
$$

\section{Accrual-based earnings management measure :}

In prior studies, accruals are commonly divided into discretionary and non-discretionary parts, in which, discretionary accruals are used as a proxy of accrual-based earnings management. (Anagnostopoulou \& Tsekrekos, 2016; Becker et al., 1998; Dechow, Sloan, \& Sweeney, 1995; DeFond \& Jiambalvo, 1994; Hribar \& Collins, 2002; Kothari, Leone, \& Wasley, 2005; Raman \& Shahrur, 2008).

In this research, we measure the accrual-based earnings management based on the modified Jones model, using adjusted by performance (Dechow et al., 1995; Kothari et al., 2005) and growth of the firm (Raman \& Shahrur, 2008).

Follow Kothari et al. (2005), discretionary accruals (DA) are calculated as the residuals from this model :

$$
\frac{T A C_{i, t}}{A_{i, t-1}}=\beta_{1} \frac{1}{A_{i, t-1}}+\beta_{2} \frac{\Delta\left(R E V_{i, t}-A R_{i, t}\right)}{A_{i, t-1}}+\beta_{3} \frac{P P E_{i, t}}{A_{i, t-1}}+\beta_{4} \frac{R O A_{i, t}}{A_{i, t-1}}+\varepsilon_{i, t}
$$

Where: TAC: total accruals, which is defined by net income subtracting cashflow from operation; DA: discretionary accruals, $N D A_{i, t}:$ Non-discretionary accruals for firm i in year $t$, At-1: Total assets for firm $j$ in year $t-1, \Delta R E V_{i, t}$ : Change in the revenues (sales) for firm $i$ in year $t$ less revenue in year $t-1, \Delta A R_{i, t}$ : Change in accounts receivables for firm $i$ in year $t$ less receivable in year $t-1, P P E_{i, t}$ : Gross properties, plants and equipment for firm i in year $t$, $R O A_{i, t}$ is the net income of firm $i$ in year $t$ scaled by the lagged total assets, $\beta_{1}, \beta_{2}, \beta_{3}, \beta_{4}, \beta_{5}$ are firm specific parameters and $\varepsilon_{i, t}$ is proxied for discretional accruals.

Raman and Shahrur (2008) adjusted Kothari's model by taking into account firm's growth. The model of Raman and Shahrur (2008) is estimated as follows:

$$
\frac{T A C_{i, t}}{A_{i, t-1}}=\beta_{1} \frac{1}{A_{i, t-1}}+\beta_{2} \frac{\Delta R E V_{i, t}}{A_{i, t-1}}+\beta_{3} \frac{P P E_{i, t}}{A_{i, t-1}}+\beta_{4} \frac{R O A_{i, t}}{A_{i, t-1}}+\beta_{5} B M_{i, t}+\varepsilon_{i, t}
$$

Where: TAC: total accruals, DA: discretionary accruals, $N D A_{i, t}:$ Non-discretionary accruals for firm $i$ in year $t$, At-1: Total assets for firm $j$ in year $t-1, \Delta R E V_{i, t}$ : Change in the 
revenues (sales) for firm $i$ in year $t$ less revenue in year $t-1, \Delta A R_{i, t}:$ Change in accounts receivables for firm $i$ in year t less receivable in year $t-1, P P E_{i, t}:$ Gross properties, plants and equipment for firm i in year $t, R O A_{i, t}$ is the net income of firm $i$ in year $t$ scaled by the lagged total assets, $\beta_{1}, \beta_{2}, \beta_{3}, \beta_{4}, \beta_{5}$ are firm specific parameters; $B M_{i, t}$ is the ratio of total asset to total asset minus the book value of equity plus market value of firm I year t and $\varepsilon_{i, t}$ is proxied for discretional accruals.

In both model (4) and (5), discretionary accrual, which indicates the level of accrual earnings management, is estimated by total accruals minus non-discretionary accruals.

$$
D A_{i, t}=\varepsilon_{i, t}=T A C_{i, t}-N D A_{i, t}
$$

To ensure the robustness of our conclusion, we employ both models of Kothari et al. (2005) (4) and Raman and Shahrur (2008) (5) to estimates discretionary accruals, denoted AEM 1 and AEM 2 respectively.

\section{Conducting research and results}

\subsection{Model and variables}

To test the hypothesis on the relationship between leverage and earning management, we estimate the panel-regression model as follows:

$$
\begin{gathered}
E M_{i, t}=E M(-1)_{i, t}+\delta_{1} L E V_{i, t}+\delta_{2} L E V H I G H_{i, t}+\delta_{3} P P E_{i, t}+\delta_{4} S I Z E_{i, t}+\delta_{5} C F O_{i, t} \\
+\delta_{6} G R O W T H_{i, t}+\varepsilon_{i, t}
\end{gathered}
$$

$\mathrm{EMi}, \mathrm{t}$ : is the level of real earnings management and accrual-based earnings management, which is mentioned in section 4.

LEV is a measure of leverage level, which is calculated by the ratio of total liabilities to total assets at year-end.

LEVHIGH is a dummy variable which is 1 if firm leverage is larger than the median of the sample in year $t$, and 0 otherwise. We use this variable to examine the effect of leverage on different earnings management strategy in the context of high leverage.

SIZE is a proxy for firm size, it is calculated by the natural logarithm of total assets at year-end. PPE is a proxy for the tangible asset; PPE is defined by tangible asset divided total assets at year-end. GROWTH is a proxy for firm growth, calculated by the ratio of revenue yearend minus revenue previous year and revenue previous year, CFO is proxy for operating cash flow, defined by cash flow divided total assets at year-end.

We incorporate firm size (SIZE), tangible assets (PPE), operating cash flow (CFO), growth opportunities (GROWTH) in the regression models as control variables. The addition of these variables is induced by the previous investigation that determined them to be correlated to earnings management (Al-dhamari \& Ku Ismail, 2015; Bazaz \& Mashayekhi, 2010; Becker et al., 1998; Chaney, Faccio, \& Parsley, 2011; Cheng \& Warfield, 2005; Reynolds \& Francis, 2000)

\subsection{Estimation method}

One problem of OLS regression is that in the case regression variables correlated with the lagged dependent variable, regression coefficient would be seriously biased (Nickell, 1981). Therefore, in our research, two-step system, especially, general method of moments (GMM) are employed to deal with the problem of heterogeneity and auto-correlation in such case Arellano and Bond (1991). 


\subsection{Data and descriptive statistics}

We use secondary data of all industry in Thomson Reuters EIKON, excluding banks, security companies, insurance companies and financial companies to measure the dependent and independent variables. Our study examines a panel data type and conducts GMM regression using the Stata program. The data set includes 241 companies on Vietnam stock markets (HNX and HOSE) in the period from 2010 to 2016. After eliminating missing value and outliers, following the above sample selection process, a total of 1687 observations are collected.

Table 1. Descriptive statistics of variables

\begin{tabular}{lcccccc}
\hline \multicolumn{1}{c}{ Variable } & Obs & Mean & Median & SD & Min & Max \\
\hline AEM 1 & 1,687 & -0.002 & 0.5175 & 2.631 & -14.723 & 55.675 \\
\hline AEM 2 & 1,687 & 0.001 & 0.6839 & 2.686 & -15.341 & 58.425 \\
\hline REM1 & 1,687 & 0.839 & 0.586 & 1.174 & -1.634 & 11.402 \\
\hline REM 2 & 1,687 & -1.231 & -0.487 & 2.824 & -17.21 & 60.103 \\
\hline LEV & 1,687 & 0.543 & 0.5745 & 0.205 & 0.032 & 0.948 \\
\hline LEVHIGH & 1,687 & 0.498 & 0.0000 & 0.501 & 0 & 1 \\
\hline PPE & 1,687 & 0.244 & 0.1864 & 0.202 & 0.000 & 0.966 \\
\hline SIZE & 1,687 & 27.379 & 27.3323 & 1.553 & 23.580 & 32.826 \\
\hline CFO & 1,687 & 0.050 & 0.0450 & 0.127 & -0.696 & 1.189 \\
\hline GROWTH & 1,687 & 0.242 & 0.0914 & 1.390 & -0.983 & 31.548 \\
\hline
\end{tabular}

Notes: The table reports summary statistics of variables over the period from 2010 to 2016 for Vietnamese listed firms. EAM is the accrual-based earnings management indicator; REM is the real earnings management indicator. LEV is a measure of leverage level, which is calculated by the ratio of debt to total assets at year-end. LEVHIGH is a dummy variable, that is 1 if firm leverage is larger than the median of the sample in year $t$, and 0 otherwise. SIZE is a proxy for firm size, it is calculated by the natural logarithm of total assets at year-end. PPE is a proxy for the tangible asset; PPE is defined by tangible asset divided total assets at year-end. GROWTH is a proxy for firm growth, calculated by the ratio of revenue year-end minus revenue previous year over revenue previous year, CFO is proxy for operating cash flow, defined by cash flow divided total assets at year-end.

Discretionary accruals in both methods of Kothari et al. (2005) (AEM 1) and Raman and Shahrur (2008) (AEM 2) present value around $-0.2 \%$ and $0.1 \%$ of total assets on average, which is generally consistent with extant research observing discretionary accrual nearly close to zero (Anagnostopoulou \& Tsekrekos, 2016; Cohen \& Zarowin, 2010). Median of discretionary accruals is positive and greater than zero ( 0.52 and 0.68 respectively), indicating a tendency of income-increasing accruals. In addition, the absolute value of REM 1 and REM 2 are significantly greater than zero in both mean ( 0.839 and -1.231 respectively) and median ( 0.586 and -0.49 respectively), revealing the presence of both upward and downward real activities manipulation. It also implies that, on average, firms have higher real earnings management than accrual-based earnings management for the sample firms used in the analysis.

Leverage ratio of Vietnamese listed firms is 0.54 on average, which the variation being from 0.32 to 0.95 . The relatively high level of using liabilities and debt is observed, indicating the importance of these source of finance among Vietnamese listed firms.

Listed companies in Vietnam ranges with different scales with a wide standard deviation and investments in PPE covering around 24\% total assets. Vietnamese listed firms also have good market performance, with revenue growth being $24 \%$ on average. 


\subsection{Results and discussion}

Table 2. Pearson correlation coefficient matrix

\begin{tabular}{|c|c|c|c|c|c|c|c|c|c|c|}
\hline & AEM 1 & AEM 2 & REM1 & REM2 & LEV & LEVHIGH & PPE & SIZE & CFO & GROWTH \\
\hline AEM 1 & 1.000 & & & & & & & & & \\
\hline AEM 2 & 0.980 & 1.000 & & & & & & & & \\
\hline REM1 & 0.360 & 0.184 & 1.000 & & & & & & & \\
\hline REM2 & 0.980 & 0.998 & 0.201 & 1.000 & & & & & & \\
\hline LEV & 0.216 & 0.220 & 0.074 & 0.234 & 1.000 & & & & & \\
\hline LEVHIGH & 0.178 & 0.182 & 0.061 & 0.191 & 0.827 & 1.000 & & & & \\
\hline PPE & -0.032 & -0.031 & -0.029 & -0.002 & -0.017 & -0.028 & 1.000 & & & \\
\hline SIZE & 0.529 & 0.567 & -0.062 & 0.570 & 0.290 & 0.253 & 0.151 & 1.000 & & \\
\hline CFO & -0.088 & -0.114 & 0.074 & -0.115 & -0.247 & -0.216 & 0.213 & -0.037 & 1.000 & \\
\hline GROWTH & 0.032 & 0.039 & -0.070 & 0.037 & 0.012 & -0.005 & -0.066 & 0.075 & -0.046 & 1.000 \\
\hline
\end{tabular}

Notes: The table reports summary statistics of variables over the period from 2010 to 2016 for Vietnamese listed firms. EAM is the accrual-based earnings management indicator; REM is the real earnings management indicator. LEV is a measure of leverage level, which is calculated by the ratio of debt to total assets at year-end. LEVHIGH is a dummy variable, that is 1 if firm leverage is larger than the median of the sample in year $t$, and 0 otherwise. SIZE is a proxy for firm size, it is calculated by the natural logarithm of total assets at year-end. PPE is a proxy for the tangible asset; PPE is defined by tangible asset divided total assets at year-end. GROWTH is a proxy for firm growth, calculated by the ratio of revenue year-end minus revenue previous year and revenue previous year, CFO is proxy for operating cash flow, defined by cash flow divided total assets at year-end.

Correlation between variables is examined to test multi-collinearity problem. We find that most of correlation between variables are low, with all coefficient being less than 0.8 , the limit to have multi-collinearity problem suggested by previous research (Gujarati \& Porter, 2003) (cited by Baatour, Ben Othman, \& Hussainey (2017)).

Table 3. Dynamic GMM- Regression results

\begin{tabular}{lcccc}
\hline & AEM 1 & AEM 2 & REM1 & REM2 \\
\hline Dependent variable & (1) & (2) & (3) & (4) \\
\hline
\end{tabular}

\begin{tabular}{|c|c|c|c|c|}
\hline AEM $1(-1)$ & $\frac{0.2163 * * *}{14.2}$ & & & \\
\hline \multirow{2}{*}{ AEM $2(-1)$} & & $0.1926 * * *$ & & \\
\hline & & 19.5 & & \\
\hline \multirow{2}{*}{ REM1 (-1) } & & & $0.7014 * * *$ & \\
\hline & & & 41.78 & \\
\hline \multirow{2}{*}{ REM2 (-1) } & & & & $0.8132 * * *$ \\
\hline & & & & 13.16 \\
\hline \multirow{2}{*}{ LEV } & $1.7805 * * *$ & $2.0346 * * *$ & $-1.2546 * * *$ & $-0.8277^{*}$ \\
\hline & 6 & 9.95 & -4.45 & -1.65 \\
\hline \multirow{2}{*}{ LEVHIGH } & $-0.3161 * * *$ & $-0.6052 * * *$ & $0.2820 * * *$ & $0.5632 * * *$ \\
\hline & -3.07 & -8.54 & 4 & 2.59 \\
\hline \multirow{2}{*}{ PPE } & $-0.6345 * * *$ & $-0.5551 * * *$ & $-0.4509 * * *$ & 0.1498 \\
\hline & -2.73 & -3.86 & -4.75 & 1.12 \\
\hline \multirow{2}{*}{ SIZE } & $0.5604 * * *$ & $0.6786 * * *$ & $0.0348 * *$ & 0.0841 \\
\hline & 12.58 & 22.42 & 2.29 & 1.35 \\
\hline \multirow{2}{*}{$\mathrm{CFO}$} & $-0.9633 * * *$ & $-0.8806 * * *$ & $2.0187 * * *$ & $-1.4534 * * *$ \\
\hline & -11.99 & -13.39 & 5.86 & -7.86 \\
\hline \multirow{2}{*}{ GROWTH } & $-0.0468 * * *$ & $-0.054 * * *$ & -0.0054 & -0.0352 \\
\hline & -6.13 & -9.45 & -0.51 & 0.53 \\
\hline
\end{tabular}




\begin{tabular}{lcccc}
\hline \multirow{2}{*}{ CONSTANT } & $-15.9022 * * *$ & $-19.1344 * * *$ & -0.1849 & -2.2341 \\
\cline { 2 - 5 } & -12.67 & -22.41 & -0.51 & -1.26 \\
\hline AR $(1)$ & 0.027 & 0.009 & 0.000 & 0.034 \\
\hline AR $(2)$ & 0.242 & 0.269 & 0.971 & 0.139 \\
\hline Hansen test & 0.16 & 0.132 & 0.139 & 0.893 \\
\hline
\end{tabular}

*,**, *** denotes the level of significance of $10 \% ; 5 \%$ and $1 \%$ respectively;

Results from regression model have statistic meaning at $1 \%$ level for both AEM 1, AEM 2 and REM 1, and at $10 \%$ for REM2, with different directions being observed. This confirms $\mathrm{H} 1$ which expect the relationships between leverage and earnings management practice. Leverage have positive association with AEM, while have adverse relationship with REM. This firstly support "debt hypothesis" that Vietnamese listed firms employed EM to avoid debt contract violations and achieve more favorable contract conditions.

In general sample, AEM is preferred to REM, which can be explained by the superior of AEM comparing to REM. REM results in the effects in company's cash flow and by using REM, companies may depart from their optimal business decisions (Graham et al., 2005). Meanwhile, AEM abuses of the flexibility of accounting principles to distort firms' performance, without impact to real cash flow. When it comes to the ability to be discovered, monitoring effects is generally considered to be less effective in the context of Vietnam. There are three main sources of finance for Vietnamese listed firms include equity market, capital market and bank system. While equity market is rather insufficient, short-term oriented and capital market is considered to be small and inactive, companies in Vietnam mainly use bank loans as their main source of finance (Phan, 2018). However, due to rapid growth rate, human resource in banking industry witnessed a dramatic increase in quantity, without corresponding improvement in quality. Only about one-third of bank employee have adequate training for their jobs (Vu, 2016), cited by Phan (2018) Moreover, in another research, we identify that in Vietnam, audit quality have no effect on earnings management due to low litigation risk (Khanh \& Nguyen, 2018).. These facts hinder the monitoring effects of banks and external parties such as auditors, creating opportunities for Vietnamese listed firms generally prefer using AEM to REM.

However, the effects of leverage on the form and extent of earnings management are different between general sample and group of high leveraged firms. Contrasting to the general sample, in high indebted firms, leverage have positive effects on REM and negative effects on AEM at $1 \%$ level. This reveals the preference for REM among high leverage firms, which is also consistent to arguments and empirical evidence of Zang (2011) and Anagnostopoulou and Tsekrekos (2016). High levels of leverage can be associated to warnings about unhealthy financial performance as well as increased credit risks and bankruptcy risks. Despite weak monitoring effects of the market, the firms still subject to the scrutiny of the creditors, investors and outsiders if it draws attention to its financial performance. In this case, the opportunities to use AEM is limited, replacing by the use of REM which covered by normal business transactions to manipulate earnings. Therefore, we accept our $\mathrm{H} 2$ hypothesis that high leverage firms prefer using real earnings management to accrual-based earnings management.

Besides, we also find that revenue growth, CFO and fixed assets investments have negative effects on upward AEM. First, the improvement in these indicators normally links to good business performance which loosen the pressure for managers to achieve their targets. Moreover, managers would limit the use of increasing income accruals as these tactics result in the expectation of higher profitability, which can be a pressure for future performance (AlNajjar \& Riahi-Belkaoui, 2001; Reynolds \& Francis, 2000). Size is found to have positive relationship with all AEM1, AEM2 and REM1. This can be explained by that large firms expose to higher 
earnings pressure (Barton \& Simko, 2002) as well as more earnings management opportunities thanks to more complex operation (Jensen \& Meckling, 1976; Y. Kim, Liu, \& Rhee, 2003).

\section{Conclusion}

In this paper, we empirically examine the effects of leverage to the forms and levels of earnings management in Vietnamese listed firms. Using data sample of Vietnam stock market, our research reports significant relationships between leverage and absolute value of discretional accruals and real earnings manipulations. This supports "debt hypothesis" that in the presence of leverage, earnings management is used to avoid debt contract violations and achieve more favorable contract conditions.

The remark of this research is the opposite preference in group of highly leveraged firms compared to in all samples being observed. In general sample comprising 1687 firm-year in Vietnam stock market from the period 2010-2016, leverage is found to have positive effects on AEM and negative effects on REM. Meanwhile, in group of highly leveraged firms, REM is more preferred to AEM. First, this highlights context of Vietnam market that monitoring effects of creditors is rather low, allows the use of AEM, exploiting accounting choices to distort company's financial performance. However, in high-debt company, high leverage level can draw a stronger interest of capital providers and limit the opportunities to use AEM. Consequently, companies might switch to REM, which are masked as daily operational activities and more difficult to be discovered. Our findings imply the substitution of REM for AEM in the context of high leverage among Vietnamese listed firms.

Our research finding have implications for researchers and capital providers. For researchers, it suggests that the investigation of only accrual-based or real earnings management in isolation is not sufficient to capture the sophisticated practice of earnings management. The forms and extent of earnings management should be viewed in a comprehensive perspective, with substitute effects being considered in different contexts. For capital providers, our finding recommends sufficient attention of both forms of earnings management in the presence of leverage. Besides, the close scrutiny of capital providers can constrain the opportunistic selections of accounting choices, but increase the use of real activities earnings management tactics.

The main limitations of this research is that we do not consider the effect of debt maturity structure. In future, we can focus on the effect of debt maturity to the levels and forms of earnings management. Especially, the directions of earnings management (upward or downward income) can also be examined in specific context. Moreover, despite the direct impact to company's cash flow, real activities manipulations are preferred in the context of high leverage to avoid the scrutiny of capital providers and outsiders. In Vietnam context, it is worth to examine the awareness of market regarding the effects of AEM and REM on the company's subsequent performance, which can be a suggestion for future research.

\section{Endnotes}

Corresponding author: Phung Anh Thu, Nguyen Tat Thanh University, Ho Chi Minh City, Vietnam.

\section{Acknowledgement}

This research is funded by University of Economics and Law, Vietnam National University Ho Chi Minh City, Vietnam. 


\section{References}

Ahn, S., \& Choi, W. (2009). The role of bank monitoring in corporate governance: Evidence from borrowers' earnings management behavior. Journal of Banking \& Finance, 33(2), 425-434.

Al-dhamari, R., \& Ku Ismail, K. N. I. (2015). Cash holdings, political connections, and earnings quality: some evidence from Malaysia. International Journal of Managerial Finance, 11(2), 215-231.

AlNajjar, F., \& Riahi-Belkaoui, A. (2001). Growth opportunities and earnings management. Managerial Finance, 27(12), 72-81.

Alsharairi, M. a. S. (2012). Does High Leverage Impact Earnings Management? Evidence from Non-cash Mergers and Acquisitions. Journal of Financial and Economic Practice, Volume 12 (1)(pp.17-33).

Alzoubi, E. S. S. (2017). Audit quality, debt financing, and earnings management: Evidence from Jordan. Journal of International Accounting, Auditing and Taxation.

Anagnostopoulou, S. C., \& Tsekrekos, A. E. (2016). The effect of financial leverage on real and accrual-based earnings management. Accounting and Business Research, 47(2), 191-236. doi:10.1080/00014788.2016.1204217

Arellano, M., \& Bond, S. (1991). Some tests of specification for panel data: Monte Carlo evidence and an application to employment equations. The review of economic studies, 58(2), 277-297.

Baatour, K., Ben Othman, H., \& Hussainey, K. J. A. R. J. (2017). The effect of multiple directorships on real and accrual-based earnings management: Evidence from Saudi listed firms. 30(4), 395-412.

Barton, J., \& Simko, P. J. (2002). The balance sheet as an earnings management constraint. The Accounting Review, 77(s-1), 1-27.

Bazaz, M. S., \& Mashayekhi, B. (2010). The effects of corporate governance on earnings quality: Evidence from Iran. Asian Journal of Business and Accounting, 3(2), 71-100.

Becker, C. L., DeFond, M. L., Jiambalvo, J., \& Subramanyam, K. (1998). The effect of audit quality on earnings management. Contemporary Accounting Research, 15(1), 1-24.

Bradshaw, M. T., Richardson, S. A., \& Sloan, R. G. (2006). The relation between corporate financing activities, analysts' forecasts and stock returns. Journal of accounting and economics, 42(1-2), 53-85.

Cai, J., \& Zhang, Z. (2011). Leverage change, debt overhang, and stock prices. Journal of Corporate Finance, 17(3), 391-402. doi:10.1016/j.jcorpfin.2010.12.003

Chaney, P. K., Faccio, M., \& Parsley, D. (2011). The quality of accounting information in politically connected firms. Journal of Accounting and Economics, 51(1-2), 58-76.

Cheng, Q., \& Warfield, T. D. (2005). Equity incentives and earnings management. The Accounting Review, 80(2), 441-476.

Cohen, D. A., Dey, A., \& Lys, T. Z. (2008). Real and accrual-based earnings management in the pre-and post-Sarbanes-Oxley periods. The Accounting Review, 83(3), 757-787.

Cohen, D. A., \& Lys, T. Z. (2006). Weighing the evidence on the relation between external corporate financing activities, accruals and stock returns. Journal of accounting and economics, 42(1-2), 87-105.

Cohen, D. A., \& Zarowin, P. (2010). Accrual-based and real earnings management activities around seasoned equity offerings. Journal of Accounting and Economics, 50(1), 2-19.

DeAngelo, H., DeAngelo, L., \& Skinner, D. J. (1994). Accounting choice in troubled companies. Journal of accounting and economics, 17(1-2), 113-143. 
Dechow, P. M., Sloan, R. G., \& Sweeney, A. P. (1995). Detecting earnings management. Accounting review, 193-225.

DeFond, M. L., \& Jiambalvo, J. (1994). Debt covenant violation and manipulation of accruals. Journal of accounting and economics, 17(1-2), 145-176.

El Diri, M. (2017). Introduction to Earnings Management: Springer.

Gao, J., Gao, B., \& Wang, X. (2017). Trade-off between real activities earnings management and accrual-based manipulation-evidence from China. Journal of International Accounting, Auditing Taxation, 29, 66-80.

Graham, J. R., Harvey, C. R., \& Rajgopal, S. (2005). The economic implications of corporate financial reporting. Journal of Accounting and Economics, 40(1-3), 3-73.

Gujarati, D. N., \& Porter, D. C. (2003). Basic Econometrics. 4th. In: New York: McGraw-Hill.

Hribar, P., \& Collins, D. W. J. J. o. A. r. (2002). Errors in estimating accruals: Implications for empirical research. 40(1), 105-134.

Jelinek, K. (2007). The effect of leverage increases on earnings management. The Journal of Business Economic Studies, 13(2), 24.

Jensen, M. C. (1986). Agency costs of free cash flow, corporate finance, and takeovers. The American economic review, 76(2), 323-329.

Jensen, M. C., \& Meckling, W. H. (1976). Theory of the firm: Managerial behavior, agency costs and ownership structure. Journal of Financial Economics, 3(4), 305-360.

Jha, A. (2013). Earnings management around debt-covenant violations-An empirical investigation using a large sample of quarterly data. Journal of Accounting, Auditing \& Finance, 28(4), 369-396.

Khanh, H. T. M., \& Nguyen, V. K. (2018). Audit quality, firm characteristics and real earnings management: The case of listed vietnamese firms. International Journal of Economics Financial Issues, 8(4), 243.

Kim, B. H., Lisic, L. L., \& Pevzner, M. J. G. M. U. W. P. (2010). Debt covenant slack and real earnings management.

Kim, Y., Liu, C., \& Rhee, S. G. (2003). The effect of firm size on earnings management. Journal College of Business Administration University of Hawai, 6, 1-30.

Kothari, S. P., Leone, A. J., \& Wasley, C. (2005). Performance matched discretionary accrual measures. Journal of accounting economics, 39(1), 163-197.

Lazzem, S., \& Jilani, F. (2018). The impact of leverage on accrual-based earnings management: The case of listed French firms. Research in International Business and Finance, 44, 350-358.

Myers, S. C. (1977). Determinants of corporate borrowing. Journal of financial economics, 5(2), 147-175.

Nickell, S. (1981). Biases in dynamic models with fixed effects. Econometrica: Journal of the Econometric Society, 1417-1426.

Nini, G., Smith, D. C., \& Sufi, A. J. C. B. S. o. B. W. P. (2009). Creditor control rights, corporate governance, and firm value.

Penman, S. H., Richardson, S. A., \& Tuna, I. (2007). The book-to-price effect in stock returns: accounting for leverage. Journal of accounting research, 45(2), 427-467.

Phan, Q. T. (2018). Corporate debt and investment with financial constraints: Vietnamese listed firms. Research in International Business Finance, 46, 268-280.

Raman, K., \& Shahrur, H. (2008). Relationship-specific investments and earnings management: Evidence on corporate suppliers and customers. The Accounting Review, 83(4), 10411081. 
Reynolds, J. K., \& Francis, J. R. (2000). Does size matter? The influence of large clients on office-level auditor reporting decisions. Journal of Accounting and Economics, 30(3), 375-400.

Roberts, M. R., \& Sufi, A. J. T. J. o. F. (2009). Control rights and capital structure: An empirical investigation. 64(4), 1657-1695.

Rodríguez-Pérez, G., \& van Hemmen, S. (2010). Debt, diversification and earnings management. Journal of Accounting and Public Policy, 29(2), 138-159.

Ronen, J., \& Yaari, V. (2008). Earnings management (Vol. 372): Springer.

Roychowdhury, S. (2006). Earnings management through real activities manipulation. Journal of accounting and economics, 42(3), 335-370. doi:10.1016/j.jacceco.2006.01.002

Sweeney, A. P. (1994). Debt-covenant violations and managers' accounting responses. Journal of accounting and economics, 17(3), 281-308.

Vo, X. V. (2017). Determinants of capital structure in emerging markets: Evidence from Vietnam. Research in International Business and Finance, 40, 105-113. doi:10.1016/j.ribaf.2016.12.001

Vu, V. (2016). Solution to improve the quality of labor in banking sector. J J. Dev. Integr., 26(36).

Watts, R., \& Zimmerman, J. (1986). Positive theory of accounting. Englewood Cliffs, NY: Prentice-Hall.

Zang, A. Y. (2011). Evidence on the trade-off between real activities manipulation and accrualbased earnings management. The Accounting Review, 87(2), 675-703. 